\title{
Analysis of the Performance of Transporting Soybeans from Mato Grosso for Export: A Case Study of the Tapajós-Teles Pires Waterway
}

\author{
Breno Tostes de Gomes Garcia ${ }^{1}$, Diana Mery Messias Lopes ${ }^{1, *}$, Ilton Curty Leal Junior ${ }^{2} \mathbb{}$, \\ José Carlos Cesar Amorim ${ }^{3}{ }^{\circledR 0}$, Marcelino Aurélio Vieira da Silva ${ }^{1}$ and \\ Vanessa de Almeida Guimarães 4 (D) \\ 1 Transportation Engineering Program, Federal University of Rio de Janeiro-UFRJ, Rio de Janeiro 21949-900, \\ Brazil; breno.garcia@pet.coppe.ufrj.br (B.T.d.G.G.); marcelino@pet.coppe.ufrj.br (M.A.V.d.S.) \\ 2 Graduate Program in Administration, Federal Fluminense University, Volta Redonda 27.213-145, RJ, Brazil; \\ iltoncurty@id.uff.br \\ 3 Military Institute of Engineering, Rio de Janeiro 22290-270, Brazil; jcamorim@ime.eb.br \\ 4 Celso Suckow da Fonseca Federal Center for Technological Education, CEFET, Angra dos Reis 23.953-030, RJ, \\ Brazil; vanessaguim@hotmail.com \\ * Correspondence: diana.mery@pet.coppe.ufrj.br
}

Received: 25 July 2019; Accepted: 25 October 2019; Published: 3 November 2019

check for updates

\begin{abstract}
The inefficiency of Brazil's logistics system to handle the outflow of farm products impairs the sector's performance. From the economic perspective, the high freight rates put the country's agricultural sector at a competitive disadvantage in the global market. Besides this, the reliance on highway transport causes problems of an environmental (high $\mathrm{CO}_{2}$ emissions) and social nature (large occurrence of accidents). As an alternative to this dependence, Brazil has an extensive network of actually and potentially navigable rivers that could serve as a key element to improve the performance of the agricultural sector. Therefore, the objective of this study is to analyze the possible influence of the Tapajós-Teles Pires Waterway on the sustainable performance of 19 Brazilian soybean export routes, using data envelopment analysis (DEA). Of these, only three would use the Tapajós-Teles Pires Waterway, which is not yet in operation. The origins of the routes are four soybean-producing centers located in Mato Grosso, the Brazilian state that produces the most soybeans, destined for 12 seaports. The inputs considered are Accident Cost and CO2 Emissions, while the output is Cargo Carried per US\$. For this, we use the DEA-VRS (Variable Return Scale) input-oriented model. The results obtained from the DEA model revealed satisfactory performance of the routes using the Tapajós-Teles Pires Waterway from three of the four production centers. In Campo Novo do Parecis, some $16 \%$ $(471 \mathrm{~km})$ of the route is composed of highways and the rest of the waterway $(84 \%, 1576 \mathrm{~km})$. In Sorriso, only $3 \%(85 \mathrm{~km})$ of the route consists of highways, while waterway transport is responsible for $97 \%$ (2388 km), and in Querência, $24.55 \%$ of the route to the Port of Barcarena consists of highways. The use of these routes and the combination of the two transport modes presented the best efficiency indexes, making development of the waterway a key element to improve the outflow of soybeans for export. The results of this study may help Brazilian authorities to define public policies and apply resources to improve the deficiencies of the transportation system, which can lead to a better balance of the Brazilian transportation matrix.
\end{abstract}

Keywords: sustainable performance analysis; carbon emission; logistics; transport costs; supply chain and fuel consumption; data envelopment analysis (DEA) 


\section{Introduction}

Global soybean output from the 2016-17 crop reached 350.84 million metric tons, of which $33.33 \%$ (116.92 million tons) was produced by the United States, followed closely by Brazil, with $32.66 \%$ of world production (114.6 million tons), 59.75\% of it exported (68.154 million tons) [1,2].

The state of Mato Grosso (MT), located in the Midwest region of Brazil, is the country's leading soybean producer, accounting for $26.75 \%$ of national output, with 30,513 million tons from the 2016-17 crop [3]. Of the quantity produced in MT, 48.48\% (14.792 million tons) was exported in 2017, worth US\$5.6 billion measured in FOB (free on board) values, representing $2.57 \%$ of Brazil's exports by value [2].

Because of the country's continental dimensions, the main disadvantage is the predominance of road transport. An example of this is the export routes between MT and the Port of Santos, the country's main outlet for this commodity, with an average distance of about $2000 \mathrm{~km}$. Besides this, some $60 \%$ of the soybeans exported travel over federal highways, such as BR-163 and BR-364 [4].

Besides the dependence on truck transport, according to the National Transport Confederation [5] the quality of the infrastructure is considered passable, poor, or very poor in $61.8 \%$ of a total of 1.7 million kilometers of highways, meaning that the highway transport infrastructure is inadequate for carrying the country's soybeans.

In contrast, in the United States, Brazil's main competitor in global agribusiness markets, the main route to export soybeans is the Mississippi River to the Port of New Orleans, which accounts for $61 \%[6]$.

The superiority of waterway transport was demonstrated by [7], who found that, in comparison with highways and railways, it presented the best results in terms of the costs of air pollution, noise pollution, accidents and external events, measured per thousand ton-km.

Due to the differences in the transport systems among countries, the costs associated with hauling soybeans can be three times higher in Brazil than in the United States. For example, farmers located in the municipality of Sorriso (MT), $2171 \mathrm{~km}$ from the Port of Santos (São Paulo state), bear a transport cost of US $\$ 80.84$ (according to [8], the average freight cost to haul soybeans in 2017 was $R \$ 305.00$ per ton- $\mathrm{km}$ ) per ton-km, while farmers in Iowa (USA), located an average of $1576 \mathrm{~km}$ from the Port of New Orleans (Louisiana), pay US $\$ 33.98$ per ton- $\mathrm{km}$, only $42 \%$ of the Brazilian costs [8].

Besides the economic impacts, mainly the cost, highway transport is the logistics operation that is most harmful to the environment, due to the large energy consumption, greenhouse gas (GHG) emissions and traffic accidents $[3,9,10]$. In the environmental dimension, the combustion of fossil fuels by transport in general in the United States is responsible for $24 \%$ of global carbon emissions [11], including $27 \%$ of the GHG emissions, while the GHG figure for Brazil is $11.9 \%$ [12]. In the social dimension, 1.35 million people were killed in roadway accidents in the world in 2016 [13].

To improve the sustainability of transportation systems, with the aim of meeting the mobility needs of the present generation without impairing the capacity of future generations to meet their own needs [14], it is necessary to identify the impacts and use indicators to evaluate the economic, environmental, and social dimensions, so that policies and strategies can be developed to reduce the impacts in these categories $[15,16]$.

Therefore, a sustainable transport system implies a better balance of the economic, environmental, and social dimensions [17], to improve the quality of logistics services (service level), spur economic development, reduce environmental degradation, and enhance social welfare [18].

According to [19], governments need to assume leadership and encourage the transport sector to place priority on developing more sustainable logistics. One way to achieve this is the application of new technologies in vehicles, such as the use of fuels from renewable sources (or hybrid vehicles), generating smaller environmental and social impacts [20].

Transport solely by railway or waterway is the best option in some regions. However, multimodality generally is the best alternative. Various research projects financed by the European Commission have addressed the question of intermodal transport, and the results have suggested that initiatives should be 
undertaken to promote this model for transport of commodities. In turn, in the USA, intermodal solutions have received strong attention since the passage of the Intermodal Surface Transportation Efficiency Act (ISTEA) and the Transportation Equity Act for the 21st Century (TEA21) [19].

According to [21], integration between different transport alternatives can maximize their potential and minimize the negative effects. [22] state that alternatives considered to be eco-friendly should be used for the longest stretches, while trucks should only have a supporting role.

In this context, Brazil has one of the world's longest coastlines (more than $7000 \mathrm{~km}$ ), as well as a vast network of navigable rivers (more than $27,000 \mathrm{~km}[23,24]$ ), making waterway transport from the interior to the coast a natural potential [25]. The most important such waterways are those of the Madeira, Tapajós, Solimões-Amazonas, Paraguay, Tocantins-Araguaia, and Paraná-Tietê rivers, as well as the proposed Southern Waterway [26].

However, the Tapajós-Teles Pires Waterway, the target of this study, is only navigable for about $280 \mathrm{~km}$, representing just $13.33 \%$ of its course [27]. Its geographic position is strategic, since it has total extension of $2100 \mathrm{~km}$ and connects large farming centers in the state of Mato Grosso to ports in the country's north region [28]. This gives rise to the following research question: If the Tapajós-Teles Pires Waterway were navigable by large vessels over its entire length, would it become the most sustainable route for export of Brazil's soybeans in the economic, environmental, and social dimensions?

Therefore, the aim of this article is to analyze the possible influence of the Tapajós-Teles Pires Waterway on the sustainable performance of 19 routes for export of Brazilian soybeans from four cities in producing regions of Mato Grosso. For this purpose, we use data envelopment analysis (DEA) as the analytic tool.

The article is structured in four sections including this introduction. The next section presents the literature review on the concepts of sustainability, circular economy (EC) and sustainable transport system. In the third section, we present the methodological procedures adopted and the origin of the data. The fourth section presents and discusses the results, and the fourth section contains our final considerations.

\section{Literature Review}

The concept of sustainability has been attracting increasing attention from the international community due to demands from society for better quality of life and the impacts of climate change caused by human activity, altering the dynamics of ecosystems, as well as economic pressures for improvement in productive processes [29,30].

Originally, the concept of sustainability focused on reducing the consumption of resources by productive activities. However, this concept has evolved to include aspects such as economic and social welfare, such as justice, human health, and environmental integrity [3,31].

The Brundtland Report [17] defined sustainable development as "development that meets the needs of the present without compromising the ability of future generations to meet their own needs." This idea indicates the need to establish limits on the use of natural resources, considering the current availability of technology and how society (social organization) manages natural resources, while considering the ability of the biosphere to absorb the effects of human activities.

The limited availability of natural resources with increasing demand for consumption means that these resources are becoming scarcer, with a parallel increase in the generation of wastes. According to [32], if the use of nonrenewable resources continues to expand at the current pace of global population growth, humankind will simply exhaust many natural resources.

Therefore, it is imperative to search for more sustainable economic models, where materials and energy from discarded products do not leave the economic system (closed system), as observed in the circular economy (CE) [33].

The idea of the CE concept assumes that natural resources are finite, in contrast to the currently prevailing paradigm of the economic system. In light of this, CE approaches consider the implementation of closed economic and physical cycles, with regenerative and restorative characteristics, 
such as maintenance, repair, reuse, refurbishment, remanufacturing, and recycling [34,35]). Therefore, the CE idea aims to achieve sustainable production and consumption, with conciliation of the economic, social and environmental aspects [36-38].

With the adoption of a CE approach, organizations can holistically obtain benefits in the economic, environmental, and social dimensions through sustainable development, such as:

- increased recycling and more efficient use of resources and greater reliance of renewable energies, to minimize the negative impacts on the global ecosystem [39];

- increased business competitiveness [40], generating social gains (job and income creation) [41,42], through greater remanufacture, refurbishment and reuse of materials, products, and components, along with extension of the useful life of products, through changes in the patterns of consumption, including shared use;

- lowering of costs, maximization of value, minimization of risks of shortages of natural resources, and sudden price fluctuations in the supply and demand for raw materials [43].

According to [44-46], sustainability should permeate all economic sectors, such as the industrial, commercial, and service sectors. In the last case, this includes the transport service sector, where the concept offers a way to reduce the impacts of the intense flow of goods around the world [47].

\section{Sustainable Transportation Systems}

The externalities generated in the environmental and social ambits of cargo transport operations have attracted strong interest from the academic community [48] and from public policymakers $[3,49,50]$. Therefore, the management of transport systems should be integrated in sustainable development strategies.

For this to become reality, the transport sector must meet economic needs (commercial relations), be easy for the public to access, and be structured to minimize the consumption of energy and emission of pollutants, along with safety, with the overall goal of improving the quality of current and future generations [51]. According to [49], a sustainable transport sector should consider the social, environmental, and economic aspects, a position corroborated by [3,31].

A sustainable transport system must reduce the consumption of energy, emission of pollutants $\left(\mathrm{CO}_{2}\right.$ and other GHGs), and maintenance costs of vehicles, besides improving the safety of roadways, railways, and waterways. For this, [52-55] stated that it is necessary to carry out actions related to:

- modal transfer to transport alternatives with greater energy efficiency;

- greater use of renewable energy sources;

- improvement of existing transport infrastructure along with the use of new vehicle technologies;

- management of supply chains with focus on reducing GHG emissions; and

- increased reliance on circular economy precepts with the objective of recycling products to obtain raw materials for the production of others.

\section{Materials and Methods}

In gathering data from the scientific literature, we considered articles related to cargo transport systems covering highway, railway, and waterway modalities, as well as articles focused on analyzing the performance of transport routes applying data envelopment analysis (DEA). Therefore, we used as search criteria a combination of the keywords "DEA" and "Freight Transport," giving preference to recent articles (from 2008 to 2018).

Besides this, due to the plentiful availability of scientific articles (magazine papers, proceedings of specialized events, among others), we used the Scopus, ScienceDirect, and Web of Science databases, focusing on the search fields Titles, Abstracts, and Keywords.

The result of this search strategy identified 49 articles. However, some were identified in more than one database, so the repetitions were excluded, along with those found not to focus on the theme of interest here. The result was seven pertinent articles. The process is depicted in Figure 1. 


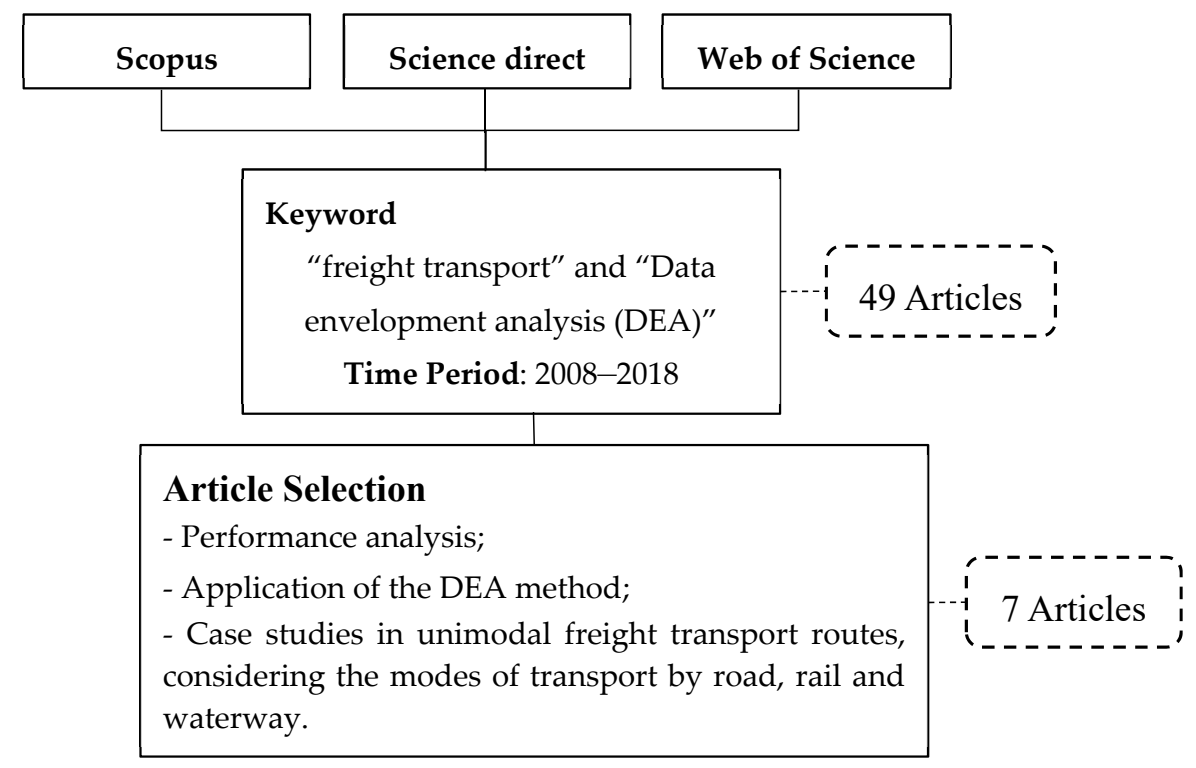

Figure 1. Flowchart of literature search.

Qualitative analysis of these articles revealed that most of those related to sustainability of cargo transport applying DEA essentially used the economic and environmental dimensions, with rare consideration of social dimensions. Besides this, the majority of the articles analyzed the roadway, railway, and waterway modes, both unimodal and intermodal. However, none of the articles analyzed the impact of implementing a waterway system for carrying farm products for export considering the economic, environmental, and social dimensions.

Reference [56] applied DEA to evaluate different transport alternatives, such as highway and a planned railroad tunnel to carry cargo between Helsinki (Finland) and Tallinn (Estonia) in light of the environmental regulations and variation of international oil prices and short-course maritime freight rates. The variables considered as inputs were time, $\mathrm{CO}_{2}$ emissions and diesel consumption in maritime transport and total costs. The output variable was quantity hauled (tons). The authors concluded that trucks had very poor performance due to high $\mathrm{CO}_{2}$ emissions and low fuel efficiency. On the other hand, ships offered faster service with reasonable freight rates. In terms of cost, the railroad tunnel and container ships could operate at the required efficiency level (or even below that estimated in the study due to the lack of volume).

Reference [57] applied the DEA method to compare the economic and environmental performance $\left(\mathrm{CO}_{2}\right.$ emissions) of Brazilian transport systems. The authors used efficiency scores to calculate the economic and ecological indexes, demonstrating how environmental performance was related to economic performance. The inputs were fuel consumption and gross value added to the economy by the transport sector, while the output variables were freight rate and number of people employed in the transport sector. In the results, 27 decision-making units (DMUs) received an economic index of 1 , in comparison with only 4 DMUs with an ecological index of 1 , demonstrating the preference for economic considerations over emission control.

Reference [58] applied DEA to a key problem of roadway cargo transport: how to rationalize measurements of GHG emissions among different transport companies. The authors developed a benchmarking approach integrating the use of weight and volume (capacity), distance traveled, and GHG emissions. The application of the DEA method demonstrated how minimization of GHG can be used to interpret the relative performance of the DMUs.

Reference [59] analyzed the soybean export corridors in the United States and Brazil, with origin in the main producing states and destination to the main soybean export ports in the two countries. The DEA-SBM method was applied to analyze the performance of the routes considering the inputs of fuel consumption, area planted, and route length, while the desirable outputs were harvest transported 
and in-farm static storage capacity, also considering the undesirable outputs fatalities, off-farm static storage capacity, emissions and disposal factor (sale of productive assets after the end of the economic cycle). The results indicated that the efficient export corridors tended to consider the railway and waterway routes over longer distances due to high capacity in a single trip. Besides this, the authors concluded that the export corridors with more than three transport modes tended to be inefficient, suggesting that there is a limit to multimodality.

Reference [60] utilized microeconomic data of the land (railway and highway) cargo transport systems in Colombia to determine the degree of allocative efficiency using the DEA method. The inputs considered were fuel, lubricants, filters, repairs, maintenance, and wages, while the output was cargo capacity. The results indicated that railway transport uses resources more efficiently than transport by trucks.

Reference [61] proposed the development of a method to select multimodal transport routes with the objective of minimizing costs, waiting time risk, and $\mathrm{CO}_{2}$ emissions. The authors used a combination of two models, AHP and DEA. The approach was tested in a realistic multimodal transport service between Bangkok (Thailand) and the Port of Da Nang (Vietnam). The results indicated that, of the 11 multimodal routes analyzed, the most efficient was the one that used only waterway transport.

Reference [62] analyzed the logistical performance of the principal corn export routes between the main producing states and ports in Brazil. For this, the authors developed a measurement system (indicators) of performance based on the Balanced Scorecard (BSC) method, considering five models to assess performance of the routes: financial, customer, internal processes, learning, and growth. Of the 17 export routes studied, the route considering highway-waterway intermodality presented the best efficiency indexes in the models developed by the authors.

\subsection{Data Envelopment Analysis (DEA)}

Data envelopment analysis (DEA) was developed by [63] and is based on linear programming, enabling the comparative analysis of multiple productive units with similar productive processes, which are characterized by the consumption of the same type of inputs to produce the same type of outputs, known as decision-making units (DMU) [64].

Because it is a nonparametric method, DEA allows for studying multiple inputs and outputs without the need to use a single measurement unit, in general monetary [65]. Besides this, the results establish a graphical frontier that is composed of the set of efficient DMUs (best management practices). The efficiency scores are measured based on the distance between the observed DMU $\left(D M U_{0}\right)$ and the efficient frontier [66].

The application of the DEA method here is justified by the large number of variables considered in the model, along with the need to collectively analyze 19 soybean export routes, as described in the following sections.

The literature describes two classic DEA models, differing in the return-to-scale characteristic, which can be constant or variable. The constant return-to-scale model (CRS) was developed by [63] and considers that the variation of inputs is proportional to the outputs. Therefore, a straight line starting at the origin of the graph [67] demarcates the configuration of the production frontier defined by DMUs.

The CRS DEA model has been proposed by [67]. Suppose there are $n$ DMUs, where each $D M U_{j}(j=1, \ldots, n)$ consumes $m$ inputs, $x_{i j}(i=1, \ldots, m)$, to produce $s$ outputs, $y_{r j}(r=1, \ldots, s)$ and $u_{r}(r=1, \ldots, s)$ and $v_{i}(i=1, \ldots, m)$ are the relative importances (weights) of each output and input, 
respectively. The input-oriented CCR DEA model Equation (1) to evaluate the performance of $D M U_{o}$ (observed DMU), and its dual form Equation (2) is as follows [68]:

$$
\begin{gathered}
\left\{\begin{array}{c}
\operatorname{Max} \sum_{r=1}^{s} u_{r} y_{r 0} \\
s . t . \\
\sum_{r=1}^{s} u_{r} y_{r j}-\sum_{i=1}^{m} v_{i} x_{i j} \leq 0, j, \ldots, n \\
\sum_{i=1}^{m} v_{i} x_{i 0}=1, \\
u_{r}>0, r=1, \ldots, s, \\
v_{i}>0, i=1, \ldots, m
\end{array}\right\} \\
\left\{\begin{array}{c}
\min \theta \\
s . t . \\
\sum_{j=1}^{n} \lambda_{j} x_{i j} \leq \theta x_{i o}, i=1, \ldots, m \\
\sum_{j=1}^{n} \lambda_{j} y_{r j} \leq \theta y_{r o}, r=1, \ldots, s \\
\lambda_{j} \geq 0, j=1, \ldots, n,
\end{array}\right\}
\end{gathered}
$$

To deal with cases where the inputs and outputs do not vary proportionally, [69] developed the variable return to scale (VRS) model, requiring alteration of the mathematical formulation of the CRS model to include a variable representing the convexity of the production frontier, according to Equations (3) and (4) [63-70].

$$
\begin{aligned}
& \left\{\begin{array}{c}
\operatorname{Max} \sum_{r=1}^{s} u_{r} y_{r 0}-u_{o} \\
\text { s.t. } \\
\sum_{r=1}^{s} u_{r} y_{r j}-u_{0}-\sum_{i=1}^{m} v_{i} x_{i j} \leq 0, j=1, \ldots, n \\
\sum_{i=1}^{m} v_{i} x_{i 0}=1, \\
u_{r}>0, r=1, \ldots, s, \\
v_{i}>0, i=1, \ldots, m
\end{array}\right\} \\
& \left\{\begin{array}{c}
\min \theta \\
\text { s.t. } \\
\sum_{j=1}^{n} \lambda_{j} x_{i j} \leq \theta x_{i o}, i=1, \ldots, m \\
\sum_{j=1}^{n} \lambda_{j} y_{r j} \leq \theta y_{r o}, r=1, \ldots, s \\
\sum_{j=1}^{n} \lambda_{j}=1 \\
\lambda_{j} \geq 0, j=1, \ldots, n,
\end{array}\right\}
\end{aligned}
$$

These two classic DEA models (CRS and VRS) allow calculating the relative efficiency, without prejudice to the DMUs with smaller production scale, by means of the ratio between outputs and inputs of the DMUs. However, the full efficiency of a determined DMU will be attained if, and only if, no input or output can be improved without worsening other inputs or outputs. This is known as Pareto-Koopmans efficiency (or Pareto efficiency) [67].

Besides this, the efficient DMUs are considered to be references for the inefficient ones, and through the envelope model, a set of targets and tolerances can be calculated to identify the changes necessary for the inefficient DMUs to become efficient-located in the production frontier [71]. 
On the other hand, one of its disadvantages is the benevolence in attributing weights to the $D M U_{0}$, for the purpose of maximizing the efficiency index, even when it is necessary to exclude a determined variable from the efficiency calculation by assigning a weight of zero to it, which may not reflect the reality of the system under analysis [63].

The production frontier is formed by the efficient DMUs, with the possibility of many DMUs integrating it. This can make it complicated to identify the most efficient DMU. Due to this, we considered the inverted frontier because this enables evaluating the DMUs from the standpoint of the worst management practices, which are calculated by the inverse of the standard efficiency index [70].

The combination of the standard and inverted efficiency indexes allows for obtaining better discrimination of the sample, because besides being in the production frontier (best management practices), the DMU must be as far as possible from the inverted frontier (worst management practices). The aggregated analysis of these two indexes results in the composite efficiency index, according to Equation (5), and the normalized composite efficiency index (Composite*), according to Equation (6) [70].

$$
\begin{gathered}
\text { Composite }=\frac{\text { Standard Effic }+(1-\text { Inverted Effic. })}{2} \\
\text { Composite }^{*}=\frac{\text { Compound }}{\max [\text { Compound }]}
\end{gathered}
$$

Here, we considered as DMUs the soybean export routes that start at the same origin (state of Mato Grosso) with maritime ports as destinations. This framework was also adopted by [62] to analyze the logistics efficiency of transporting corn for export. Besides this, the criterion of homogeneity was satisfied by considering the same variables (inputs and outputs) in all the export routes, as also presented by [58], who analyzed the performance of logistics corridors (DMUs) to carry soybeans from MT for export.

\subsection{Soybean Export Routes from Mato Grosso}

The export routes for soybeans were defined based on the producing municipalities in MT (origins, herein called production centers), chosen considering the quantity produced in 2017 and the position in the geographic region of the state. In other words, when two production centers were in the same geographic region, the municipality with the lowest output was removed. This led to the selection of four production centers (municipalities): Campo Novo de Parecis, Querência, Sorriso, and Rondonópolis (Figure 2).

As destinations, we selected the ten leading Brazilian ports in terms of soybeans handled for export in 2017, as depicted in Figure 3. In that year, the Port of Santos (São Paulo state) handled about 16.218 million tons (19.49\% of the national total). It was followed by the ports of Rio Grande (Rio Grande do Sul), Paranaguá (Paraná), and Vila do Conde (Pará), with respective movements of 13.564 million (16.3\%), 11.454 million (13.76\%), and 7.349 million $(8.83 \%)$ tons [2,72].

The routes considered in this study are presented in Table 1 (Routes used for outflow of soybeans from the production centers to the destination ports), which identifies the origins (production centers), destinations (maritime ports), stopping places for transshipment (transshipment city), paths (routes), and transport modes considered. 


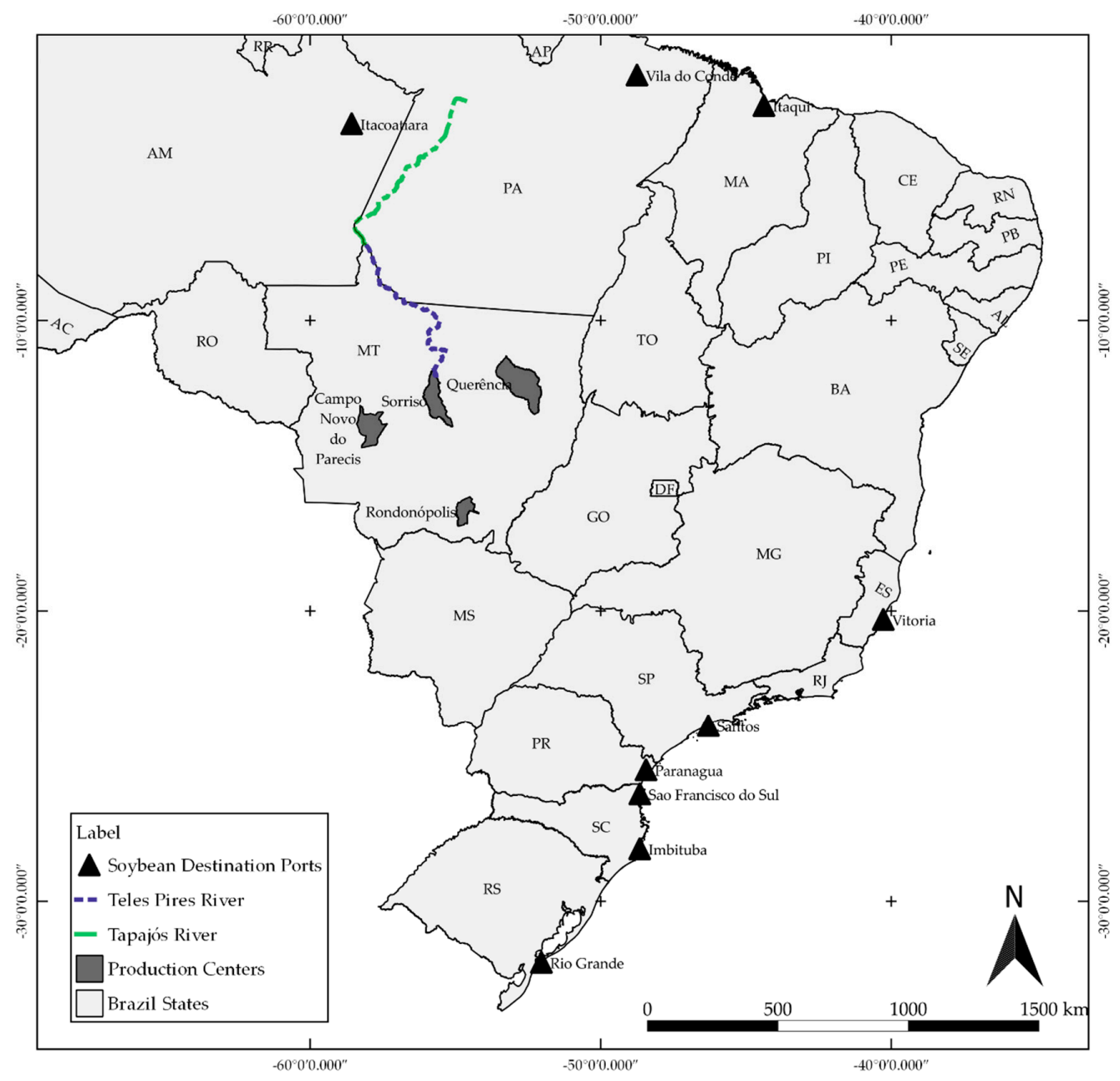

Figure 2. Main maritime ports for Brazilian soybean exports.

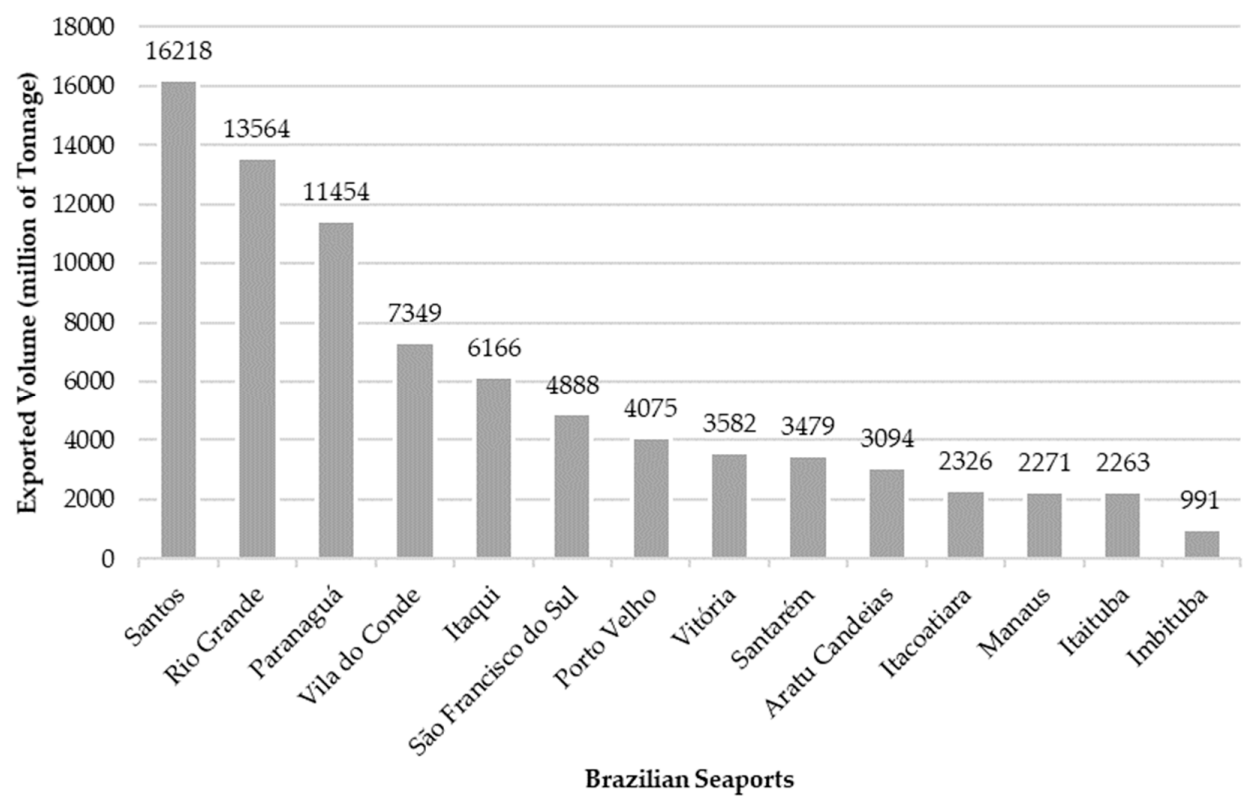

Figure 3. Soybeans exported (tonnage) through Brazilian maritime ports in 2017. 
Table 1. Routes used for outflow of soybeans from the production centers to the destination ports.

\begin{tabular}{|c|c|c|c|c|c|c|c|}
\hline \multirow{2}{*}{ DMU } & Production Centers & \multicolumn{5}{|c|}{ Route Characterization } & \multirow{2}{*}{$\begin{array}{l}\text { Maritime } \\
\text { Ports }\end{array}$} \\
\hline & $\begin{array}{l}\text { Campo Novo } \\
\text { de Parecis }\end{array}$ & Paths & Tranship. City & Paths & $\begin{array}{l}\text { Tranship. } \\
\text { City }\end{array}$ & Paths & \\
\hline 1 & Roadway-Railway & $\begin{array}{l}\text { BR 163, BR 364, BR 452, BR 242, BR 251, } \\
\text { BR 070 }\end{array}$ & Araguari (MG) & $\begin{array}{l}\text { FCA e EVFM } \\
\text { Railway }\end{array}$ & - & - & Vitória \\
\hline 2 & Roadway & BR163, BR 364, BR 242, BR 251, BR 070 & - & - & - & - & Santos \\
\hline 3 & Roadway-Railway & BR 163, BR 242, BR 251, BR 070 & Rondonópolis (MT) & ALLMN Railway & - & - & Santos \\
\hline 4 & Roadway-Railway & BR 163, BR 364, BR 242, BR 251, BR 070 & Alto Araguaia (MT) & ALLMN Railway & - & - & Santos \\
\hline 5 & Roadway-Waterway (Tiete-Paraná Waterway)-Railway & BR 163, BR 364, BR 242, BR 251, BR 070 & São Simão (GO) & Tietê Waterway & $\begin{array}{l}\text { Pederneiras } \\
\text { (SP) }\end{array}$ & $\begin{array}{l}\text { ALLMM } \\
\text { Railway }\end{array}$ & Santos \\
\hline 6 & Roadway-Waterway (Tapajós and Amazonas River) & BR 163, BR 242, BR 251, BR 070 & Miritituba (PA) & $\begin{array}{l}\text { Tapajós, Amazonas } \\
\text { e Pará Waterway }\end{array}$ & - & - & $\begin{array}{l}\text { Vila do } \\
\text { Conde }\end{array}$ \\
\hline 7 & Roadway-Waterway (Amazonas River) & BR 163, BR 242, BR 251, BR 070 & Santarém (PA) & $\begin{array}{c}\text { Amazonas e Pará } \\
\text { Waterway }\end{array}$ & - & - & $\begin{array}{l}\text { Vila do } \\
\text { Conde }\end{array}$ \\
\hline 8 & Roadway-Waterway (Madeira e Amazonas River) & BR 163, BR 364, BR 242, BR 251, BR 070 & Porto Velho (RO) & $\begin{array}{l}\text { Madeira, Amazonas } \\
\text { e Pará Waterway }\end{array}$ & - & - & $\begin{array}{l}\text { Vila do } \\
\text { Conde }\end{array}$ \\
\hline 9 & Roadway-Waterway (Tapajos-Teles Pires River) & BR 163, BR 242, BR 251, BR 070 & $\begin{array}{c}\text { Cachoeira Rasteira } \\
\text { (Apiacás-MT) }\end{array}$ & $\begin{array}{l}\text { Tapajós, Teles Pires } \\
\text { Waterway }\end{array}$ & - & - & $\begin{array}{l}\text { Vila do } \\
\text { Conde }\end{array}$ \\
\hline 10 & Roadway-Waterway (Tapajos-Teles Pires River) & BR 163, BR 242, BR 251, BR 070 & Sinop (MT) & $\begin{array}{l}\text { Tapajós, Teles Pires } \\
\text { Waterway }\end{array}$ & - & - & $\begin{array}{l}\text { Vila do } \\
\text { Conde }\end{array}$ \\
\hline 11 & Roadway-Waterway (Tapajos-Teles Pires River) & BR 163, BR 242, BR 251, BR 070 & $\begin{array}{l}\text { Cachoeira Rasteira } \\
\text { (Apiacás-MT) }\end{array}$ & $\begin{array}{l}\text { Tapajós, Teles Pires } \\
\text { Waterway }\end{array}$ & - & - & Santarém \\
\hline 12 & Roadway-Waterway & BR 163, BR 242, BR 251, BR 070 & Itaituba (PA) & Tapajós Waterway & - & - & Santarém \\
\hline 13 & Roadway-Waterway (Madeira River) & BR 163, BR 364, BR 242, BR 251, BR 070 & Porto Velho (RO) & Madeira Waterway & & & Itacoatiara \\
\hline 14 & Roadway & $\begin{array}{l}\text { BR 163, BR 267, BR 376, BR 242, BR 251, } \\
\text { BR 070 }\end{array}$ & - & - & - & - & Paranaguá \\
\hline 15 & Roadway-Railway & BR 163, BR 267, BR 242, BR 251, BR 070 & Maringá (PR) & ALLMS Railway & - & - & Paranaguá \\
\hline 16 & Roadway & $\begin{array}{c}\text { BR 163, BR 267, BR 376, BR 487, BR 466, } \\
\text { BR277, BR 242, BR 251, BR } 070\end{array}$ & - & - & - & - & $\begin{array}{c}\text { São } \\
\text { Francisco do } \\
\text { Sul }\end{array}$ \\
\hline 17 & Roadway-Railway & BR 163, BR 242, BR 251, BR 070 & Cruz Alta (RS) & ALLMS Railway & - & - & Rio Grande \\
\hline 18 & Roadway & $\begin{array}{c}\text { BR 163, BR 267, BR 376, BR 487, BR 466, } \\
\text { BR277, BR 242, BR 251, BR 070 }\end{array}$ & & & - & - & Imbituba \\
\hline 19 & Roadway-Railway & $\begin{array}{l}\text { BR 158, PA 287, TO 335, BR 242, BR 251, } \\
\text { BR } 070\end{array}$ & Palmeirante (TO) & EFC Railway & - & - & São Luís \\
\hline
\end{tabular}

Note: “-" There isn't neither transshipment city nor transshipment city. 
According to Table 1, DMU 3 has the peculiarity, that besides being a production center, Rondonópolis is also a transshipment city for trains, while the other production centers use trucks to carry cargo to the transshipment city of Rondonópolis. Despite this, the homogeneity criterion is not altered because it shares the same objective of moving the output of soybeans and uses the same inputs and outputs, as mentioned in Section 3.1 (Data Envelopment Analysis)

Figure 4 (Routes to carry soybeans to maritime ports in the South and Southeast regions of the country) depicts the export routes considered in this study to haul soybeans to the ports located in the South and Southeast regions of the country, while Figure 5 (Routes to carry soybeans to maritime ports in the North region of the country).

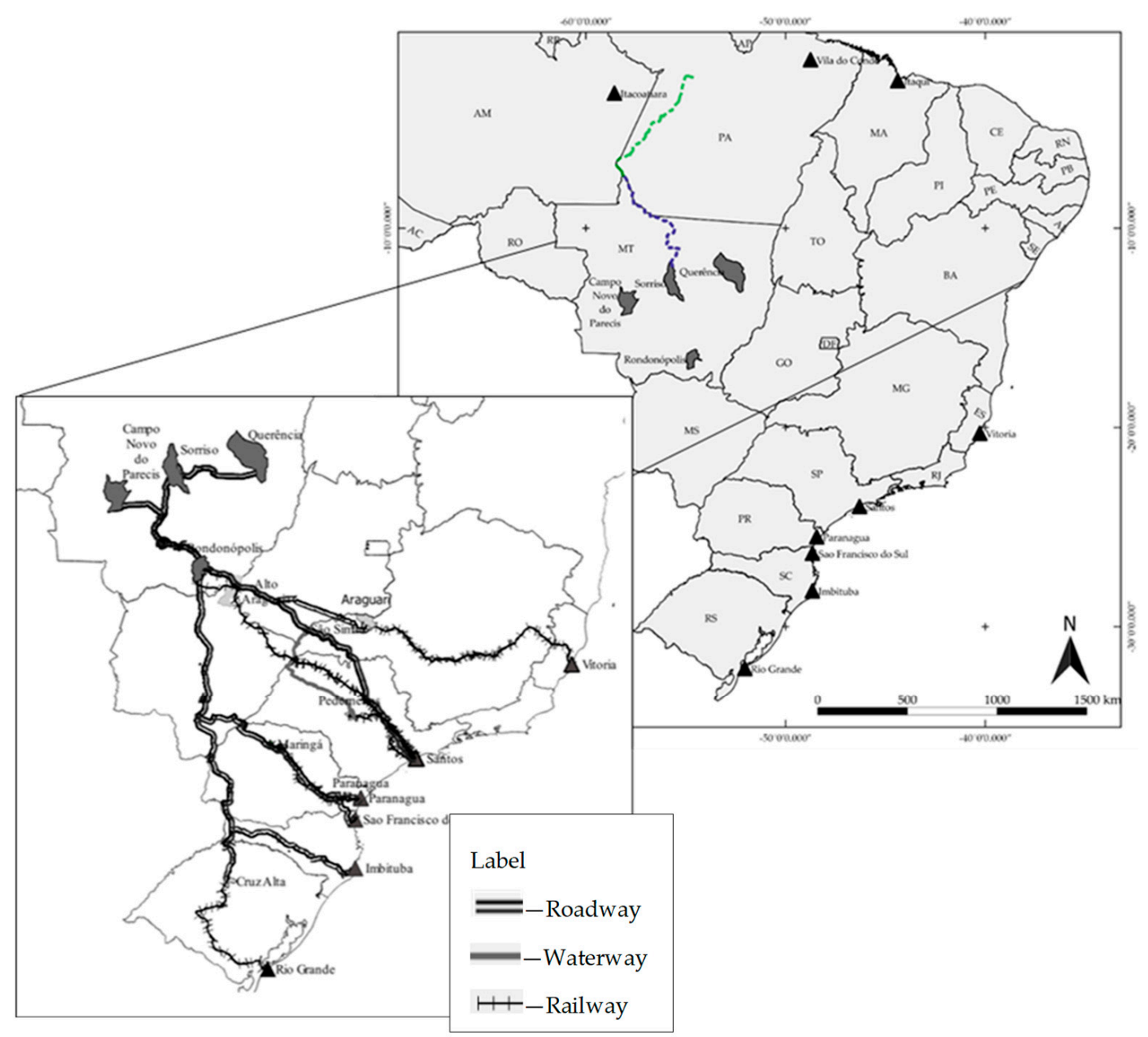

Figure 4. Routes to carry soybeans to maritime ports in the South and Southeast regions of the country.

Presents the routes to the ports located in the North region.

To identify the most sustainable route(s), we employed the variables presented in the next section (Section 3.3). 


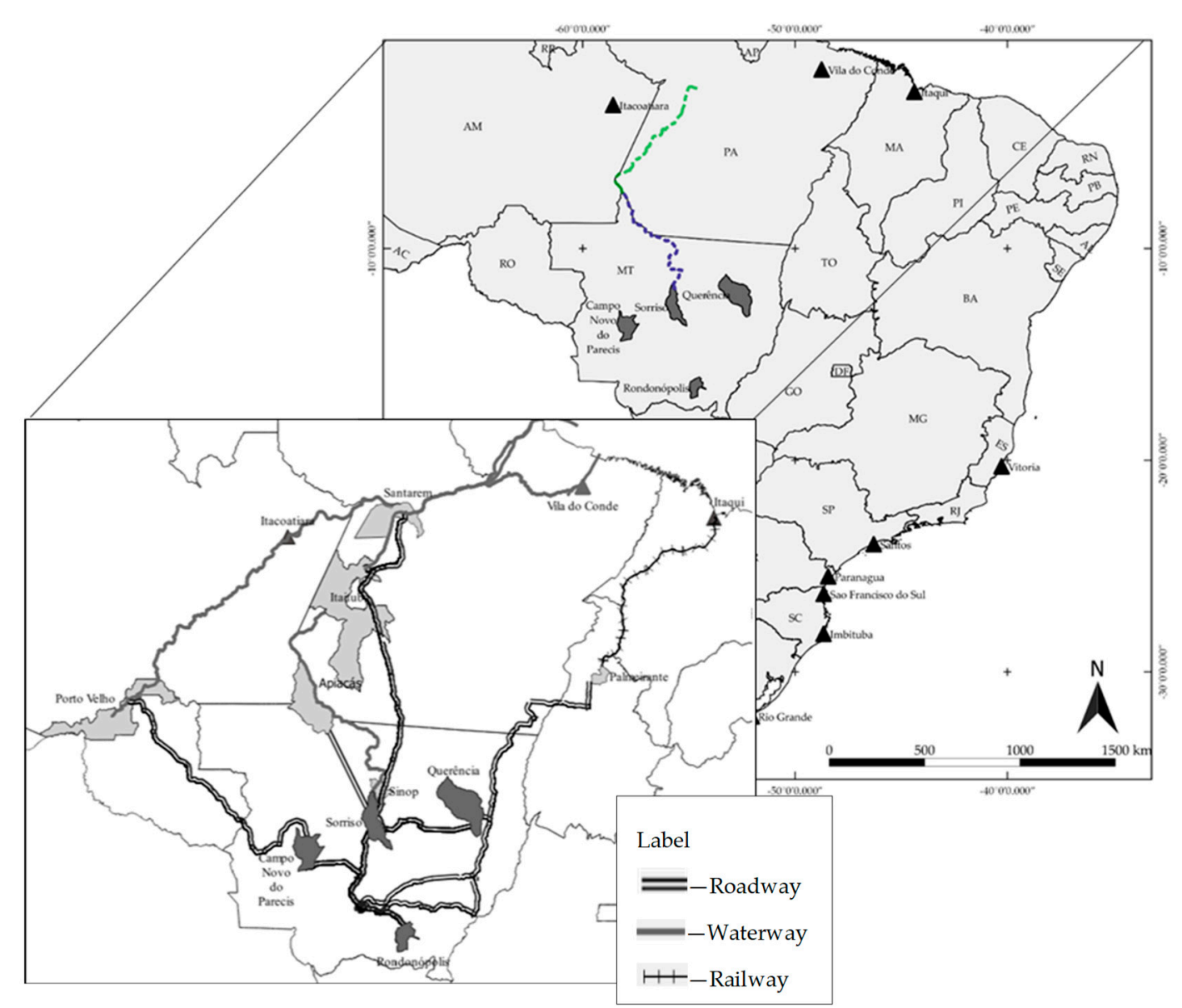

Figure 5. Routes to carry soybeans to maritime ports in the North region of the country.

\subsection{Selection of the Variables}

The information extracted from the articles was: DEA model(s) considered; variables of the problem, in view of the economic, environmental, and social aspects; and transport modes (roadway, railway, and waterway), as presented in Table 2 (Result of the search for articles that have applied the DEA method to analyze cargo transport systems).

As shown in Table 2, the most common economic variable from the literature review was fuel consumption. In the environmental aspect, the variable pertaining to GHG emissions was present in about $70 \%$ of the articles, making it the leading variable.

Finally, only two papers applied a variable associated with the social aspects. One paper considered the number of people employed in the transport sector and the other, the number of fatal accidents. The sample obtained here indicated that few academic works have considered variables involving the social dimension using the DEA method as a tool to solve problems of freight transport systems. A clearer picture of the literature would require expanding the search by consulting other databases and using other combinations of keywords.

On the other hand, the variables involving GHG emissions were most frequent, which can indicate better acceptance by researchers of this measure to analyze cargo transport systems. Finally, we did not find any articles using a variable measuring the weight of cargo carried per monetary unit, considered in this work as a variable of the economic aspect. The inputs and outputs are presented as follows. 
Table 2. Result of the search for articles that have applied the DEA method to analyze cargo transport systems.

\begin{tabular}{|c|c|c|c|c|c|c|c|}
\hline \multirow{2}{*}{ Authors } & \multicolumn{3}{|c|}{ Transport Mode } & \multirow{2}{*}{$\begin{array}{l}\text { DEA Model and } \\
\text { Orientation }\end{array}$} & \multicolumn{3}{|c|}{ Variables Used } \\
\hline & Road & Rail & Water & & Environmental & Economic & Social \\
\hline [56] & $x$ & $X$ & $X$ & CCR-input & - Emission of $\mathrm{CO}_{2}$ & $\begin{array}{l}\text { - } \quad \text { Fuel consumption } \\
\text { - } \quad \text { Gross value added to the } \\
\text { economy of the transport sector } \\
\text { - } \quad \text { Cargo carried (tons) }\end{array}$ & $\begin{array}{l}\text { - Number of people } \\
\text { employed in the } \\
\text { transport sector }\end{array}$ \\
\hline [59] & $x$ & $x$ & & $\begin{array}{l}\text { VRS and } \\
\text { CCR-input and } \\
\text { output oriented }\end{array}$ & - & $\begin{array}{ll}\text { - } & \text { Fuel consumption } \\
\text { - } & \text { Cargo capacity } \\
\text { - } & \text { Consumption of lubricants } \\
\text { - } & \text { Consumption of filters } \\
\text { - } & \text { Repair and maintenance costs } \\
\text { - } & \text { Wages }\end{array}$ & - \\
\hline$[60]$ & $x$ & $x$ & $x$ & DEA/AHP/ZOGP & - Emission of $\mathrm{CO}_{2}$ & $\begin{array}{ll}\text { - } & \text { Transport costs } \\
\text { - } & \text { Transport time } \\
\text { - } & \text { Risk } \\
\end{array}$ & - \\
\hline [55] & $X$ & $X$ & $x$ & $\begin{array}{l}\text { CCR-input and } \\
\text { output }\end{array}$ & - Emission of $\mathrm{CO}_{2}$ & $\begin{array}{ll}\text { - } & \text { Delivery time } \\
\text { - } & \text { Consumption of diesel } \\
\text { - } & \text { Total costs } \\
\text { - } & \text { Cargo carried (tons) } \\
\end{array}$ & - \\
\hline [57] & $x$ & & & $\begin{array}{l}\text { VRS-undesirable } \\
\text { output model }\end{array}$ & $\begin{array}{l}\text { Emission of greenhouse } \\
\text { gases (GHG) }\end{array}$ & $\begin{array}{ll}\text { - } & \text { Weight } \\
\text { - } & \text { Volume } \\
\text { - } & \text { Distance }\end{array}$ & - \\
\hline
\end{tabular}


Table 2. Cont.

\begin{tabular}{|c|c|c|c|c|c|c|c|}
\hline \multirow{2}{*}{ Authors } & \multicolumn{3}{|c|}{ Transport Mode } & \multirow{2}{*}{$\begin{array}{l}\text { DEA Model and } \\
\text { Orientation }\end{array}$} & \multicolumn{3}{|c|}{ Variables Used } \\
\hline & Road & Rail & Water & & Environmental & Economic & Social \\
\hline$[58]$ & $X$ & $x$ & $x$ & SBM & $\begin{array}{l}\text { Elimination factor (sale of } \\
\text { productive assets after the } \\
\text { end of the economic cycle) } \\
\text { - } \quad \text { Emissions of pollutants }\end{array}$ & $\begin{array}{ll}\text { - } & \text { Fuel consumption } \\
\text { - } & \text { Area planted } \\
\text { - } & \text { Static storage capacity outside } \\
\text { - } & \text { the farm } \\
\text { - Harvest carried }\end{array}$ & $\begin{array}{l}\text { Occurrence of } \\
\text { fatal accidents }\end{array}$ \\
\hline$[61]$ & $X$ & $X$ & $x$ & VRS-output & $\begin{array}{ll}\text { - } & \begin{array}{l}\text { Sustainable development } \\
\text { (learning and }\end{array} \\
\text { growth dimension) } \\
\text { - } & \text { Fuel consumption } \\
\text { - } & \text { Fleet age } \\
\text { - } & \text { Composition of the } \\
\text { transport matrix }\end{array}$ & 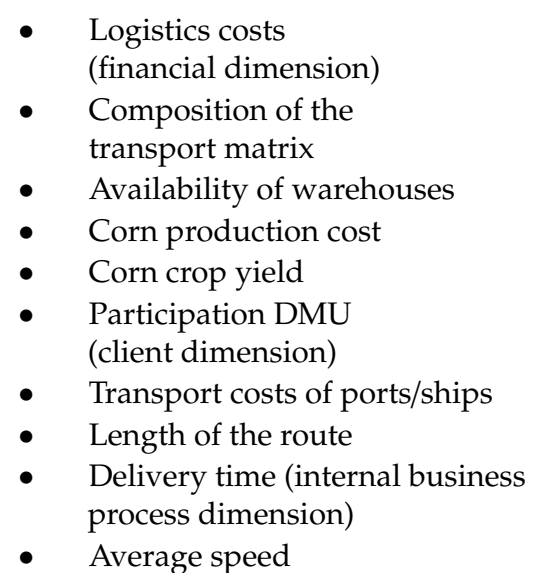 & - \\
\hline
\end{tabular}




\subsubsection{Cost of Accidents}

The accident cost (US\$/t.km), adopted here as a social aspect, can be considered an undesired result of the process of hauling soybeans. However, its impact falls in all three categories: economic (losses of product), environmental (soil contamination by the product carried), and social (human fatalities). According to [73], the scope of social and environmental impacts is perceived in particular by people who live near highways. The implications are that the local people can alter the choice of their routine routes of movement due to the perceived risk of undesired events (such as accidents) involving highway transport. [72] stated that the occurrence of accidents has two aspects, those related to the accident itself, such as damage to the vehicle, labor for repairs, emergency services, insurance, traffic jams, etc.; and those related to the people involved, such as loss of life, loss of income, medical costs, pain and suffering, etc. In this study, we considered the second aspect, due to the possible influence in the social ambit.

The method to calculate the accident cost (AC) was obtained from the doctoral thesis of [73], given by the ratio between the total accident cost (TAC-US\$) and cargo transportation (CT-1000 t.Km), as presented in Equation (7):

$$
A C=\frac{T A C}{C P}
$$

The values resulting from each transport mode are reported in Table 3 [74].

Table 3. Accident costs for each transport mode.

\begin{tabular}{cccc}
\hline Modes & TAC (US\$) & CT (1000 t.km) & AC (US\$/(1000 t.km)) \\
\hline Waterway & $61,294.426$ & $1,272,000$ & 0.0482 \\
Railway & $41,906,527,789$ & $164,809,000$ & 0.2543 \\
Highway & $456,666,790,703$ & $485,625,000$ & 0.9404 \\
\hline
\end{tabular}

\subsubsection{Emission of $\mathrm{CO}_{2}$}

According to [74], of the economic sectors in a country, the transportation sector is responsible for the largest emission of greenhouse gases (GHG), with trucks and buses being the leading emitters, while air and waterway transportation contribute the least to total emissions.

In quantitative terms, [75] indicated that roadway cargo transport emits $79 \mathrm{gCO}_{2} / \mathrm{TKU}$, while railway and waterway transportation emit, respectively, $12 \mathrm{gCO}_{2} / \mathrm{TKU}$ and $9 \mathrm{gCO}_{2} / \mathrm{TKU}$, making trucking, by far, the most polluting mode. It is thus relevant to consider this structure when evaluating the performance of routes (DMUs) from an environmental standpoint.

In this study, emission of $\mathrm{CO}_{2}$ - measured in $\mathrm{Kg} \times \mathrm{CO}_{2} /$ ton-was considered an undesired output, for the same reasons as discussed regarding the occurrence of accidents variable.

\subsubsection{Cost per Ton of Cargo Carried in US\$}

The formation of prices in cargo transport (freight charges) considers, among other factors, the structure of costs, which tends to be related to the characteristics of the transport services, such as distance traveled, load volume, cargo density, and handling requirements, among others [76].

Of note, [77] presented the soybean freight costs as one of the four bottlenecks in the supply chain of that crop. The unit to measure this variable is Monetary Unit/Ton of Cargo Carried. Thus, it is a variable that must be minimized, but in this study we applied the inverse, as denoted by Equation (8): Ton of Cargo Carried/ Monetary Unit, turning it into a variable to be maximized in the DEA model.

$$
E_{f}=\text { Freight } \operatorname{Cost}^{-1}
$$


Since the American dollar is the most widely used currency in international trade in general, we converted all monetary values in Brazilian currency (the Real, R\$) into dollars at the average exchange rate for sale of dollars in June 2018, of R\$3.7731/US\$, as quoted by the Brazilian Central Bank [78].

Table 4 (Data of the variables of the 19 DMUs considered in this study) presents the variables of the problem, along with the characteristics of the DMUs, production centers, and respective maritime ports considered.

In this study, the travel time variable was not considered, because, according to [79], interviews with some soybean growers in the state of MT revealed that travel time did not influence the route choice for exportation. According to the author, the difference in travel time was one to two days.

Besides this, the volume of cargo transported was not considered because the Tapajós-Teles Pires Waterway is not yet operational, although the Brazilian government is planning to implement it [79].

We adopted the VRS DEA model by considering variations of production scales in the efficiency calculations, because it permits identifying the technical efficiency of export routes. The input orientation is most suitable due to the objective of minimizing the externalities of the export routes, while maintaining the output. Figure 6 (DEA model adopted in this study) depicts the configuration of the variables of the DEA model.

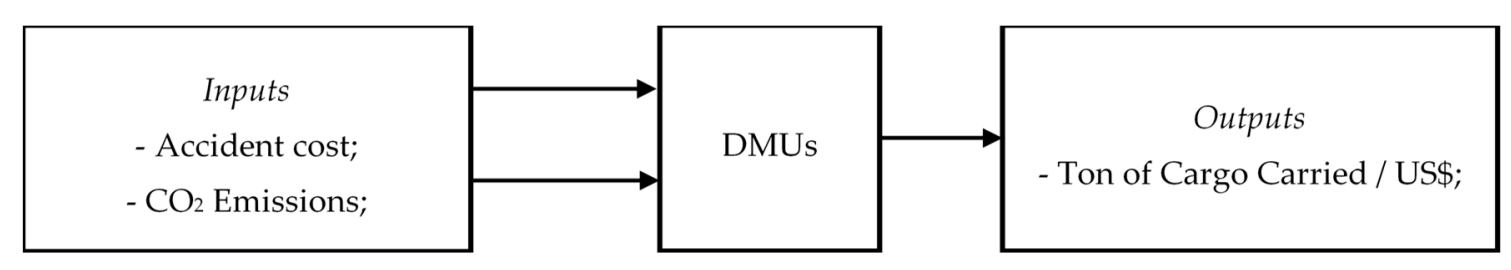

Figure 6. DEA model adopted in this study.

Because of the use of undesirable variables (accident cost and emission of $\mathrm{CO}_{2}$ ) in this study, we employed the "incorporating undesirable output as input" (INP) approach, as used by [79] and [80], where the undesirable outputs are treated as inputs. 
Table 4. Data of the variables of the 19 DMUs considered in this study.

\begin{tabular}{|c|c|c|c|c|c|c|c|c|c|c|c|c|c|c|}
\hline \multirow[b]{2}{*}{ DMU } & \multirow[b]{2}{*}{ Ports } & \multirow[b]{2}{*}{$\begin{array}{c}\text { Uses the } \\
\text { Tapajós-Teles } \\
\text { Pires waterway }\end{array}$} & \multicolumn{3}{|c|}{ Querência } & \multicolumn{3}{|c|}{ Sorriso } & \multicolumn{3}{|c|}{ Campo Novo Parecis } & \multicolumn{3}{|c|}{ Rondonópolis } \\
\hline & & & Emissions & $\begin{array}{c}\text { Accident } \\
\text { Cost }\end{array}$ & Ton,/US\$ & Emissions & $\begin{array}{c}\text { Accident } \\
\text { Cost }\end{array}$ & Ton,/US\$ & Emissions & $\begin{array}{c}\text { Accident } \\
\text { Cost }\end{array}$ & Ton,/US\$ & Emissions & $\begin{array}{c}\text { Accident } \\
\text { Cost }\end{array}$ & Ton,/US\$ \\
\hline 1 & Vitória (ES) & & 125.32 & 1.43 & 0.010 & 146.404 & 1.69 & 0.009 & 145.873 & 1.68 & 0.009 & 98.464 & 1.097 & 0.011 \\
\hline 2 & Santos (SP) & & 142.15 & 1.76 & 0.014 & 150.493 & 1.87 & 0.013 & 150.341 & 1.86 & 0.013 & 105.209 & 1.304 & 0.017 \\
\hline 3 & Santos (SP) & & 92.47 & 1.00 & 0.011 & 93.686 & 1.01 & 0.011 & 91.638 & 0.99 & 0.011 & 44.457 & 0.400 & 0.017 \\
\hline 4 & Santos (SP) & & 97.93 & 1.09 & 0.011 & 99.368 & 1.10 & 0.011 & 99.217 & 1.10 & 0.011 & 51.808 & 0.515 & 0.017 \\
\hline 5 & Santos (SP) & & 96.20 & 1.02 & 0.012 & 117.593 & 1.28 & 0.011 & 116.986 & 1.28 & 0.011 & 69.729 & 0.690 & 0.015 \\
\hline 6 & Barcarena (PA) & & 151.13 & 1.65 & 0.011 & 103.414 & 1.06 & 0.014 & 133.073 & 1.43 & 0.011 & 151.126 & 1.651 & 0.011 \\
\hline 7 & Barcarena (PA) & & 167.70 & 1.91 & 0.010 & 120.211 & 1.33 & 0.012 & 149.718 & 1.69 & 0.011 & 167.771 & 1.915 & 0.010 \\
\hline 8 & Barcarena (PA) & & 198.99 & 1.96 & 0.008 & 160.079 & 1.48 & 0.009 & 130.269 & 1.11 & 0.011 & 177.070 & 1.689 & 0.009 \\
\hline 9 & Barcarena (PA) & $x$ & 114.86 & 1.05 & 0.012 & 88.539 & 0.72 & 0.015 & 117.819 & 1.08 & 0.012 & 134.506 & 1.291 & 0.011 \\
\hline 10 & Barcarena (PA) & $x$ & 107.30 & 0.85 & 0.012 & 54.784 & 0.19 & 0.020 & 84.087 & 0.56 & 0.014 & 104.567 & 0.812 & 0.012 \\
\hline 11 & Santarém (PA) & $x$ & 109.43 & 1.03 & 0.013 & 83.112 & 0.71 & 0.016 & 112.391 & 1.07 & 0.013 & 129.079 & 1.278 & 0.011 \\
\hline 12 & Santarém (PA) & & 162.27 & 1.90 & 0.012 & 114.784 & 1.31 & 0.014 & 144.291 & 1.68 & 0.013 & 162.344 & 1.902 & 0.012 \\
\hline 13 & Itacoatiara (AM) & & 193.91 & 1.95 & 0.009 & 154.996 & 1.47 & 0.010 & 125.186 & 1.10 & 0.011 & 171.987 & 1.677 & 0.009 \\
\hline 14 & Paranaguá (PR) & & 161.04 & 2.00 & 0.012 & 168.546 & 2.09 & 0.012 & 166.953 & 2.07 & 0.012 & 121.517 & 1.506 & 0.016 \\
\hline 15 & Paranaguá (PR) & & 133.18 & 1.59 & 0.012 & 149.867 & 1.80 & 0.011 & 150.019 & 1.80 & 0.011 & 99.728 & 1.177 & 0.014 \\
\hline 16 & $\begin{array}{c}\text { São Francisco do } \\
\text { Sul (SC) }\end{array}$ & & 161.04 & 2.00 & 0.011 & 168.546 & 2.09 & 0.011 & 166.953 & 2.07 & 0.011 & 121.517 & 1.506 & 0.015 \\
\hline 17 & $\begin{array}{l}\text { Porto do Rio } \\
\text { Grande (RS) }\end{array}$ & & 198.18 & 2.39 & 0.008 & 195.300 & 2.35 & 0.008 & 195.679 & 2.36 & 0.008 & 145.540 & 1.735 & 0.011 \\
\hline 18 & Imbituba (SC) & & 180.91 & 2.24 & 0.010 & 188.420 & 2.34 & 0.010 & 186.827 & 2.32 & 0.010 & 141.391 & 1.753 & 0.013 \\
\hline 19 & Itaqui (PA) & & 77.34 & 0.81 & 0.012 & 111.166 & 1.23 & 0.009 & 136.956 & 1.55 & 0.009 & 129.324 & 1.464 & 0.009 \\
\hline
\end{tabular}

Note: The " $\mathrm{X}$ " is to highlight the routes that use the tapajós-teles pires waterway. 


\section{Analysis and Discussion of the Results}

This section is presented in two steps of analysis, in which the first steps present the performance of the routes in a general context. We consider the Composite* Index, which allows us to identify the most efficient of the 19 routes for each production center. In the second step, we analyze the routes that use the Tapajós-Teles Pires Waterway (DMUs 9, 10, and 11), to identify the targets to be attained for these routes to become efficient, if not originally efficient.

In the first step, DMU 10 presented the highest value of the Composite* Index in Campo Novo do Parecis and Sorriso. This means that it is the most efficient route in these production centers (Figure 7). In Querência, this route is on the efficiency frontier. However, it is not the most efficient.

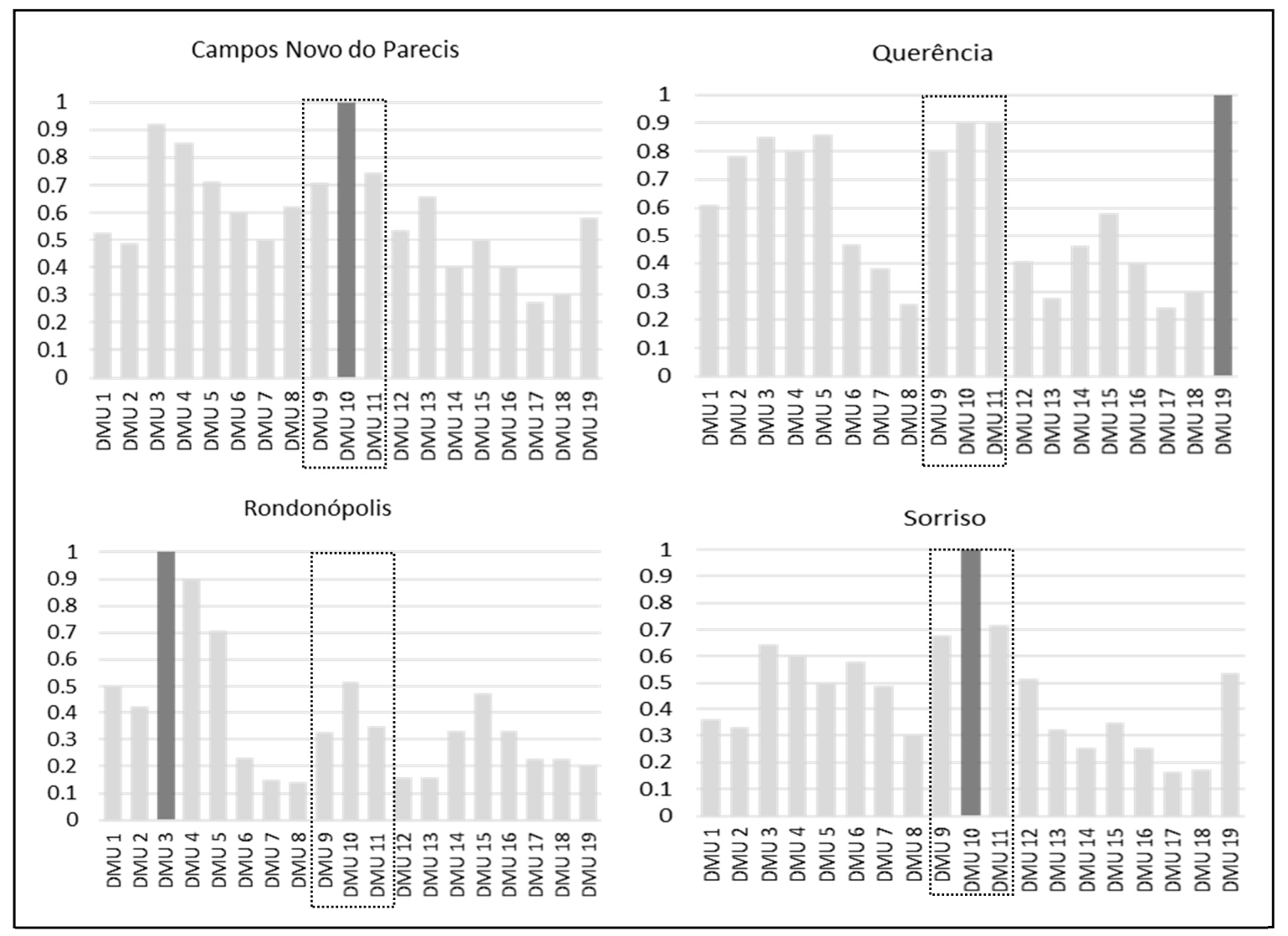

Figure 7. The normalized composite efficiency index (Composite*).

DMU 19 is the most efficient route in Querência. This route presented the lowest values of $\mathrm{CO}_{2}$ emission and accident cost, attributed to the intermodality between highway and railway carriage. Besides this, it can be said that the lesser dependence on trucking is related to the better performance of this route, given that $24 \%(462 \mathrm{~km})$ is by highway and the other $76 \%(1500 \mathrm{~km})$ is traveled by trains of the company Ferrovia Norte-Sul (FNS, "North-South Railroad").

Figure 7 presents the Composite* Index values of the DMUs for each production center, highlighting the export routes that would use the Tapajós-Teles Pires Waterway (DMUs 9, 10, and 11), as indicated by the broken line.

Finally, in the Rondonópolis production center, DMU 3 had the best performance, due to the direct connection with the Port of Santos by railway. The benefits of this mode can be observed in the lower values of $\mathrm{CO}_{2}$ emissions and accident costs.

In step 2, we analyzed only the routes using the Tapajós-Teles Pires Waterway (DMUs 9, 10, and 11), seeking to identify the targets to be met to become efficient. DMU 10 was the most efficient in Campo Novo do Parecis and Sorriso. In the first, the route consisted of 16\% (471 km) highway and 
the rest waterway $(84 \%, 1576 \mathrm{~km})$, while in the second the breakdown was $3 \%(85 \mathrm{~km})$ by highway and $97 \%(2388 \mathrm{~km})$ by waterway. Therefore, it can be stated that trucking played only a supporting role to waterway transport, with greater operational capacity. The influence of intermodality on the performance of transport routes was also observed by [21] and [22].

Next, the analyses of the routes are presented in the context of each production center.

\subsection{DMU 9}

DMU 9 did not perform satisfactorily in any of the production centers considered. For this route to become Pareto-efficient in Campo Novo do Parecis, the $\mathrm{CO}_{2}$ emission must be reduced by $71.37 \%$, to meet the target of $84.086 \mathrm{~kg} \times \mathrm{CO}_{2} /$ ton (Table 5 . Variable values to be achieved (target) for DMU 9 to become an efficient export route in Campo Novo de Parecis). In turn, the accident cost needs to be reduced from the current value of 1.0843 to 0.558 US $\$ 1000 / \mathrm{t} . \mathrm{km}$, a reduction of $51.46 \%$. However, besides these reductions, it is also necessary to adjust the amount of output from the current 0.0122 to 0.0144 ton/US\$, an increase of $18.64 \%$.

Table 5. Variable values to be achieved (target) for DMU 9 to become an efficient export route in Campo Novo de Parecis.

\begin{tabular}{ccc}
\hline Campo Novo do Parecis & Current Value & Target Value \\
\hline $\mathrm{CO}_{2}$ Emission & 117.8187 & 84.0866 \\
Accident Cost & 1.0843 & 0.5580 \\
Cargo Transportation/US\$ & 0.0122 & 0.0144 \\
\hline
\end{tabular}

In Querência, for this route to become efficient, it is necessary to reduce the $\mathrm{CO}_{2}$ emissions from the current 114.86 to $100.28 \mathrm{~kg} \times \mathrm{CO}_{2} /$ ton and the accident costs from 0.2777 to $0.2424 \mathrm{US} \$ 1000 / \mathrm{t} . \mathrm{km}$, a decrease of $12.69 \%$ of both inputs (Table 6. Variable values to be achieved (target) for DMU 9 to become an efficient export route in Querência.).

Table 6. Variable values to be achieved (target) for DMU 9 to become an efficient export route in Querência.

\begin{tabular}{ccc}
\hline Querência & Current Value & Target Value \\
\hline Emission & 114.8604 & 100.2887 \\
Accident Cost & 0.2776 & 0.2424 \\
Cargo Transportation/US\$ & 0.0124 & 0.0124 \\
\hline
\end{tabular}

In Sorriso, the $\mathrm{CO}_{2}$ emissions must be cut by $38.12 \%$, from the present 88.54 to $54.78 \mathrm{~kg} \times \mathrm{CO}_{2} /$ ton (Table 7. Variable values to be achieved (target) for DMU 9 to become an efficient export route in Sorriso), while the accident cost needs to be reduced from 0.7213 to 0.19474 US $\$ 1000 / t . k m$, a reduction of $26.99 \%$. Besides this, the output needs to be reduced by $38.80 \%$ to meet the target of 0.0203 ton/US\$.

Table 7. Variable values to be achieved (target) for DMU 9 to become an efficient export route in Sorriso.

\begin{tabular}{ccc}
\hline Sorriso & Current Value & Target Value \\
\hline $\mathrm{CO}_{2}$ Emission & 88.5393 & 54.7844 \\
Accident Cost & 0.7213 & 0.1947 \\
Cargo Transportation/US\$ & 0.0146 & 0.0203 \\
\hline
\end{tabular}

Finally, in Rondonópolis, the $\mathrm{CO}_{2}$ emissions need to be reduced by $66.95 \%$, from the current 134.506 to $44.45 \mathrm{~kg} \times \mathrm{CO}_{2} / \mathrm{ton}$. In turn, the accident cost needs to be cut from the present 1.291 to 0.4002 US\$1000/t.km, a decrease of $69.00 \%$. However, to become Pareto-efficient, the output needs to 
be increased by $58.41 \%$, as presented in Table 8 (Variable values to be achieved (target) for DMU 9 to become an efficient export route in Rondonópolis).

Table 8. Variable values to be achieved (target) for DMU 9 to become an efficient export route in Rondonópolis.

\begin{tabular}{ccc}
\hline Rondonópolis & Current Value & Target Value \\
\hline $\mathrm{CO}_{2}$ Emission & 134.5064 & 44.4571 \\
Accident Cost & 1.2912 & 0.4002 \\
Cargo Transportation/US\$ & 0.0109 & 0.0173 \\
\hline
\end{tabular}

With respect to the targets to be met and the percentage of highway transport in relation to the total distance covered, in Sorriso, highways cover $26.59 \%$ of the route connecting it to the Port of Barcarena (PA), resulting in the third highest Composite* Index value in relation to the routes from this origin (Sorriso). The worst result was observed in Rondonópolis, where the Composite* Index was the 11th highest of the sample, which can be explained by the relatively high percentage of highways $(40.79 \%)$ in relation to the total route.

\section{2. $\mathrm{DMU} 10$}

This route was efficient in Querência, Campo Novo do Parecis, and Sorriso, in these last two production centers presenting the highest Composite* Index value.

In Rondonópolis, the production center in which DMU 10 was not efficient, the only efficient export route was DMU 3, since it was exclusively covered by rail to the destination, the Port of Santos (SP).

For DMU 10 to become efficient in the Rondonópolis production center (Table 9. Variable values to be achieved (target) for DMU 10 to become an efficient export route in Rondonópolis), it is necessary to reduce the accident cost by $50.70 \%$, from the current value of 0.8119 to $0.4002 \mathrm{US} \$ 1000 / \mathrm{t} . \mathrm{km}$, while the $\mathrm{CO}_{2}$ emissions need to diminish from the present 104.567 to $44.457 \mathrm{~kg} \times \mathrm{CO}_{2} / \mathrm{ton}$, a reduction of $57.48 \%$. Besides this, the quantity of cargo carried per US\$ needs to rise by $38.27 \%$ to meet the target of 0.0173 ton/US\$.

Table 9. Variable values to be achieved (target) for DMU 10 to become an efficient export route in Rondonópolis.

\begin{tabular}{ccc}
\hline Rondonópolis & Current Value & Target Value \\
\hline $\mathrm{CO}_{2}$ Emission & 104.5670 & 60.1098 \\
Accident Cost & 1.2912 & 0.40023 \\
Cargo Transportation/US\$ & 0.0125 & 0.0173 \\
\hline
\end{tabular}

According to the results of the targets to be met and the percentage of waterway transport use, in Sorriso, the transportation mode accounts for $96.57 \%$ of the distance traveled to the Port of Barcarena (PA), resulting in the highest efficiency value of the Composite ${ }^{*}$ Index, making this route the most efficient with origin in Sorriso.

In Querência, the route consists of $75.45 \%$ by waterway to the Port of Barcarena (PA), making it efficient, but not the most efficient of all the routes from this origin. However, in Rondonópolis, the most efficient route connects Rondonópolis to the Port of Santos by rail.

\subsection{DMU 11}

Due to the unsatisfactory performance over the route from Campo Novo do Parecis to the Port of Santarém (PA), the $\mathrm{CO}_{2}$ emissions must be reduced by $25.18 \%$, to a target value of $84.086 \mathrm{~kg} \times \mathrm{CO}_{2} /$ ton, while the accident cost must be reduced from the current 1.074 to 0.5580 US $\$ 1000 / \mathrm{t} . \mathrm{km}, 47.92 \%$ lower. Besides this, the ton of cargo per US $\$$ must be increased from the present 0.0128 to 0.0144 ton/US\$, 
or by $12.49 \%$ (Table 10. Variable values to be achieved (target) for DMU 11 to become an efficient export route in Campo novo do Parecis.).

Table 10. Variable values to be achieved (target) for DMU 11 to become an efficient export route in Campo novo do Parecis.

\begin{tabular}{ccc}
\hline Campo Novo do Parecis & Current Value & Target Value \\
\hline $\mathrm{CO}_{2}$ Emission & 112.3914 & 84.0866 \\
Accident Cost & 1.0714 & 0.5580 \\
Cargo Transportation/US\$ & 0.0128 & 0.0144 \\
\hline
\end{tabular}

In Querência, this route presented satisfactory performance, meaning it is in the production frontier, although not being the most efficient route, with the third highest Composite* Index (Figure 7. The normalized composite efficiency index (Composite $\left.{ }^{*}\right)$.

For this route to become efficient in Sorriso, the $\mathrm{CO}_{2}$ emissions need to be decreased by $34.08 \%$, from the current 83.112 to the target of $54.784 \mathrm{~kg} \times \mathrm{CO}_{2} / \mathrm{ton}$. In turn, the accident cost needs to be reduced from the current 0.7084 to 0.19471 US $\$ 1000 / \mathrm{t} . \mathrm{km}$, or by $72.51 \%$. Finally, the ton of cargo per US\$ metric must increase by $30.14 \%$, from the current value of 0.0156 to 0.0203 ton/US\$ (Table 11 . Variable values to be achieved (target) for DMU 11 to become an efficient export route in Sorriso.).

Table 11. Variable values to be achieved (target) for DMU 11 to become an efficient export route in Sorriso.

\begin{tabular}{ccc}
\hline Sorriso & Current Value & Target Value \\
\hline $\mathrm{CO}_{2}$ Emission & 83.1120 & 54.7844 \\
Accident Cost & 0.7084 & 0.19471 \\
Cargo Transportation/US\$ & 0.0156 & 0.0203 \\
\hline
\end{tabular}

In Rondonópolis, the $\mathrm{CO}_{2}$ emissions must be reduced by $65.56 \%$ to meet the target of 44.457 $\mathrm{kg} \times \mathrm{CO}_{2} /$ ton, and the accident cost must decline from the current figure of 0.8119 to the target of 0.4002 US $\$ 1000 / \mathrm{t} . \mathrm{km}$, a reduction of $50.70 \%$. Finally, the ton of cargo per US\$ must be increased by $51.05 \%$, from the current value of 0.0114 to 0.0173 ton/US\$ (Table 12. Variable values to be achieved (target) for DMU 11 to become an efficient export route in Rondonópolis).

Table 12. Variable values to be achieved (target) for DMU 11 to become an efficient export route in Rondonópolis.

\begin{tabular}{ccc}
\hline Rondonópolis & Current Value & Target Value \\
\hline $\mathrm{CO}_{2}$ Emission & 129.0791 & 44.4572 \\
Accident Cost & 1.2783 & 0.40023 \\
Cargo Transportation/US\$ & 0.0114 & 0.0173 \\
\hline
\end{tabular}

Comparison of the results of the targets to be reached and the percentage use of waterway transport shows that the Composite* Index for this route was the best in Sorriso (MT), with $70.25 \%$ of the distance traveled by waterway. In turn, Rondonópolis presented $55.39 \%$ of the distance by highway, the highest value of this route, with the other production centers obtaining the lowest ranking in the Composite* Index.

\section{Conclusions}

This study analyzed the influence of the Tapajós-Teles Pires Waterway on the performance of export routes to transport soybean production from the state of Mato Grosso, Brazil, to export ports, focusing on sustainability. This waterway is not yet in operation, but there is a plan by the Brazilian 
government to adapt its infrastructure for cargo transportation operations. In light of this, the results of this study can help the country's authorities define public policies and apply resources to improve the efficiency of the transport system, leading to a better balance among the modes of transport in Brazil.

The results showed that the export routes using the Tapajós-Teles Pires Waterway had high efficiency indexes in three of the four production centers (Campo Novo do Parecis, Querência, and Sorriso). In Rondonópolis, the waterway did not present satisfactory performance because of the superiority of unimodal transport by train to the Port of Santos (SP) (DMU 3).

The results obtained in this study are similar to those found in the literature consulted. Of the more sustainable routes, there was predominance of intermodality as an alternative to reduce logistics costs, as also observed by [81].

Of the more sustainable routes with intermodal combinations of highway-railroad or highway-waterway, the results show the importance of the Tapajós-Teles Pires Waterway as the most sustainable option for soybean exports from Mato Grosso.

The routes that presented the lowest efficiency indexes predominantly rely on highways over long distances, so improvement would be achieved by shifting to high-capacity modes (rail and/or water), as reported by [82].

Because of the great importance of soybean farming to the Brazilian economy, especially the state of Mato Grosso, various investments are being made to try to alleviate logistical bottlenecks. The National Logistics and Transport Plan (PNLT) is an initiative created by the Brazilian government in 2007 to resolve these bottlenecks. The PNLT contains a series of guidelines for investments needed for the country to improve its logistics efficiency, and was revised in 2009 and 2011 [82-84]. One of these guidelines is to develop the Tapajós-Teles Pires Waterway, making the river system navigable in nearly all its extension and doubling the quantity of exports from the region served by the waterway by 2031. Another factor that will increase the potential for river transport is the so-called shift to ports of the north region, away from ports in the southeast region (Vitória, Santos, and Paranaguá). The expectation is that, by 2023, 50\% of the exports from Mato Grosso will use ports in the North.

In light of the possibility of increasing the volume of grains exported through the ports in northern Brazil, we suggest that future studies consider other indicators related to sustainability of routes, besides analyzing the possible influence on the operational performance of the port sector on the sustainable performance of the Tapajós-Teles Pires Waterway. Besides this, we recommend attributing weights to the inputs and outputs model to obtain precise results of the DEA model. We also mention using other DEA methods, such as the I-O-Stepwise and DEA-SBM models, among others. Another suggestion is to assign weights to model inputs and outputs for more accurate DEA model results. Finally, we suggest analyzing the behavior of the routes pairwise according to the DEA results.

Author Contributions: All authors contributed equally to this paper.

Funding: This research received no external funding.

Acknowledgments: This study was financed in part by the Coordenação de Aperfeiçoamento de Pessoal de Nível Superior-Brazil (CAPES) -Finance Code 001; and we thank CNPq (Process 310825/2017-2 Research Productivity Fellowship Holder-CNPq Brazil) for financial support.

Conflicts of Interest: The authors declare no conflict of interest.

\section{References}

1. USDA. World Agricultural Production; Cornell University: Washington, DC, USA, 2018.

2. Brazil Portal ComexStat. Available online: http://comexstat.mdic.gov.br/pt/geral (accessed on 24 April 2019).

3. Litman, T.; Burwell, D. Issues in sustainable transportation. Int. J. Glob. Environ. Issues 2006, 6, 331-347. [CrossRef]

4. IMEA. Entendendo o Mercado da Soja; Instituto Mato-Grossense de Economia Agropecuária (IMEA): Cuiabá, MT, Brazil, 2015. 
5. Brazil. Anuário CNT do transporte: estatísticas consolidadas 2018; Confederação Nacional do Transportes (CNT): Brasília, DF, Brazil, 2018.

6. Wilhelmi, C.R.; Danao, M.G.C.; Gates, R.S.; Zandonadi, R.S.; Hansen, A.C. Condition assessment of trucks used for soybean transport in Mato Grosso, Brazil. In Proceedings of the American Society of Agricultural and Biological Engineers Annual (ASABE), Montreal, QC, Canada, 13-16 July 2014; Volume 5, pp. 3361-3371.

7. Gołębiowski, C. Inland Water Transport in Poland. Transp. Res. Procedia 2016, 14, 223-232. [CrossRef]

8. Brazil Historical Series of Harvests. Available online: https://www.conab.gov.br/info-agro/safras/seriehistorica-das-safras?start=20 (accessed on 25 Apirl 2019).

9. Rogers, M.M.; Weber, W.L. Evaluating $\mathrm{CO}_{2}$ emissions and fatalities tradeoffs in truck transport. Int. J. Phys. Distrib. Logist. Manag. 2011, 41, 750-767. [CrossRef]

10. Wu, H.; Dunn, S.C. Environmentally responsible logistics systems. Int. J. Phys. Distrib. Logist. Manag. 1995, 25, 20-38. [CrossRef]

11. EPA. Inventory of U.S. Greenhouse Gas Emissions and Sinks 1990-2017; United States Environmental Protection Agency (EPA): Washington, DC, USA, 2019; Volume 53.

12. De Azevedo, T.R.; Costa Junior, C.; Brandão Junior, A.; dos Santos Cremer, M.; Piatto, M.; Tsai, D.S.; Barreto, P.; Martins, H.; Sales, M.; Galuchi, T.; et al. SEEG initiative estimates of Brazilian greenhouse gas emissions from 1970 to 2015. Sci. Data 2018, 5, 1-43. [CrossRef] [PubMed]

13. WHO. Global Status Report on Road Safety 2018; World Health Organization (WHO): Geneva, Switzerland, 2018.

14. Richardson, B.C. Toward a Policy on a Sustainable Transportation System. Transp. Res. Rec. J. Transp. Res. Board 1999, 1670, 27-34. [CrossRef]

15. Cottrill, C.D.; Derrible, S. Leveraging Big Data for the Development of Transport Sustainability Indicators. J. Urban Technol. 2015, 22, 45-64. [CrossRef]

16. Dobranskyte-Niskota, A.; Perujo, A.; Jesinghaus, J.; Jensen, P. Indicators to Assess Sustainability of Transport Activities - Part 2: Measurement and Evaluation of Transport Sustainability Performance in the EU27; European Commission (EC): Ispra, Italy, 2009.

17. WCED. Our Common Future; World Commission on Environment and Development (WCED): New York, NY, USA, 1987.

18. Steg, L.; Gifford, R. Sustainable transportation and quality of life. J. Transp. Geogr. 2005, 13, 59-69. [CrossRef]

19. Kelle, P.; Song, J.; Jin, M.; Schneider, H.; Claypool, C. Evaluation of operational and environmental sustainability tradeo ff $\mathrm{s}$ in multimodal freight transportation planning. Int. J. Prod. Econ. 2019, 209, 411-420. [CrossRef]

20. Marousek, J. Use of continuous pressure shockwaves apparatus in rapeseed oil processing. Clean Technol. Environ. Policy 2013, 15, 721-725. [CrossRef]

21. Wiśnicki, B.; Dyrda, A. Analysis of the Intermodal Transport Efficiency in the Central. Naše More 2016, 63, 43-47. [CrossRef]

22. Flodén, J.; Williamsson, J. Business models for sustainable biofuel transport: The potential for intermodal transport. J. Clean. Prod. 2016, 113, 426-437. [CrossRef]

23. Godoy, P.R.C. De O estado da arte das hidrovias brasileiras. In Proceedings of the II Fórum Sobre Hidrovia - As hidrovias como fator de desenvolvimento brasileiro; Departamento Nacional de Infraestrutura de Transportes (DNIT): Brasília, DF, Brazil, 2011.

24. Soares, M.M. A evolução das hidrovias brasileiras visão da CNT. In Proceedings of the $2^{\circ}$ Fórum Sobre Hidrovia - As hidrovias como fator de desenvolvimento brasileiro; ANTAQ: Brasília, Brazil, 2011.

25. De Valois, N.A.L.; Medina, A.C.; Botter, R.C. Potential of short sea shipping in Brazil; Rizzuto, E., Soares, C.G., Eds.; Taylor \& Francis Group: São Paulo, Brazil, 2012; ISBN 978-0-415-62081-9.

26. Kaiser, I.M.; Bezerra, B.S.; Castro, L.I.S. Is the environmental policies procedures a barrier to development of inland navigation and port management? A case of study in Brazil. Transp. Res. Part A Policy Pract. 2013, 47, 78-86. [CrossRef]

27. Brazil. Plano Nacional de Integração Hidroviária (PNIH) - Relatório Executivo: Bacia Amazônica; Agência Nacional de Transportes Aquaviários (ANTAQ): Brasília, DF, Brazil, 2013.

28. Brazil. Plano Hidroviário Estratégico (PHE) - Diagnóstico e Avaliação; Ministério da Infraestrutura: Brasília, DF, Brazil, 2013. 
29. Dey, A.; Laguardia, P.; Srinivasan, M. Building sustainability in logistics operations: a research agenda. Manag. Res. Rev. 2011, 34, 1237-1259. [CrossRef]

30. Palsson, H.; Johansson, O. Reducing transportation emissions: Company intentions, barriers and discriminating factors. Benchmarking An Int. J. 2016, 23, 674-703. [CrossRef]

31. De Almeida Guimarães, V.; Junior, I.C.; da Silva, M.A. Evaluating the sustainability of urban passenger transportation by Monte Carlo simulation. Renew. Sustain. Energy Rev. 2018, 93, 732-752. [CrossRef]

32. Ramos, A.G. A nova ciência das organizações: uma reconceituação da riqueza das nações, 2nd ed.; Getúlio Vargas Foundation: Rio de Janeiro, Brazil, 1989.

33. Fonseca, L.M.; Domingues, J.P.; Pereira, M.T.; Martins, F.F.; Zimon, D. Assessment of circular economy within Portuguese organizations. Sustainability 2018, 10, 2521. [CrossRef]

34. Genovesea, A.; Acquayeb, A.A.; Figueroaa, A.; Koh, S.C.L. Sustainable supply chain management and the transition towards a circular economy: Evidence and some applications. Omega 2017, 66, 344-357. [CrossRef]

35. Yap, N.T. Towards a Circular Economy: Progress and Challenges. Greener Manag. Int. 2005, 11-24.

36. EEA. Circular economy in Europe. Developing the knowledge base; European Environment Agency: Luxembourg, 2016.

37. George, D.A.R.; Lin, B.C.; Chen, Y. A circular economy model of economic growth. Environ. Model. Softw. 2015, 73, 60-63. [CrossRef]

38. Lieder, M.; Rashid, A. Towards circular economy implementation: a comprehensive review in context of manufacturing industry. J. Clean. Prod. 2016, 115, 36-51. [CrossRef]

39. Ellen MacArthur Foundation. Delivering the Circular Economy. A Toolkit for Policymakers; Danish Business Authority: Copenhagen, Denmark, 2015.

40. Bastein, T.; Roelofs, E.; Rietveld, E.; Hoogendoorn, A. Opportunities for a Circular Economy in the Netherlands; TNO: Delft, The Netherlands, 2013.

41. Rizos, V.; Tuokko, K.; Behrens, A. The Circular Economy A review of definitions, processes and impacts; Centre for European Policy Studies (CEPS): Berlim, Germany, 2017.

42. Morgan, J.; Mitchell, P. Employment and the Circular Economy: Job Creation in a More Resource Efficient Britain; Morgan, J., Mitchell, P., Eds.; Green Alliance: London, UK, 2015.

43. Shaharudin, M.S.; Fernando, Y.; Chiappetta Jabbour, C.J.; Sroufe, R.; Jasmi, M.F.A. Past, present, and future low carbon supply chain management: A content review using social network analysis. J. Clean. Prod. 2019, 218, 629-643. [CrossRef]

44. Bretzke, W.-R. Sustainable logistics: in search of solutions for a challenging new problem. Logist. Res. 2011, 3, 179-189. [CrossRef]

45. De Campos, R.S.; Simon, A.T.; de Campos Martins, F. Assessing the impacts of road freight transport on sustainability: A case study in the sugar-energy sector. J. Clean. Prod. 2019, 220, 995-1004. [CrossRef]

46. Dekker, R.; Bloemhof, J.; Mallidis, I. Operations Research for green logistics - An overview of aspects, issues, contributions and challenges. Eur. J. Oper. Res. 2012, 219, 671-679. [CrossRef]

47. Litman, T.A. Well Measured: Developing Indicators for Sustainable and Livable Transport Planning; Victoria Transport Policy Institute: Victoria, BC, Canada, 2019.

48. Santos, G.; Maoh, H.; Potoglou, D.; Brunn, T. Von Factors influencing modal split of commuting journeys in medium-size European cities. J. Transp. Geogr. 2013, 30, 127-137. [CrossRef]

49. Santos, A.S.; Ribeiro, S.K. The use of sustainability indicators in urban passenger transport during the decision-making process: The case of Rio de Janeiro, Brazil. Curr. Opin. Environ. Sustain. 2013, 5, 251-260. [CrossRef]

50. Buehler, R.; Pucher, J.; Kunert, U. Making Transportation Sustainable: Insights from Germany; Metropolitan Policy Program: Washington, DC, USA, 2009.

51. Figueroa, M.J.; Ribeiro, S.K. Energy for road passenger transport and sustainable development: Assessing policies and goals interactions. Curr. Opin. Environ. Sustain. 2013, 5, 152-162. [CrossRef]

52. Zarkadoula, M.; Zoidis, G.; Tritopoulou, E. Training urban bus drivers to promote smart driving: A note on a Greek eco-driving pilot program. Transp. Res. Part D Transp. Environ. 2007, 12, 449-451. [CrossRef]

53. Barth, M.; Boriboonsomsin, K. Real-World Carbon Dioxide Impacts of Traffic Congestion. UC Berkeley Univ. Calif. Transp. Cent. 2010. [CrossRef]

54. Barkenbus, J.N. Eco-driving: An overlooked climate change initiative. Energy Policy 2010, 38, 762-769. [CrossRef] 
55. Hilmola, O.P.; Lorentz, H.; Rhoades, D.L. New environmental demands and the future of the Helsinki-Tallinn freight route. Marit. Econ. Logist. 2015, 17, 198-220. [CrossRef]

56. Su, J.; Rogers, M.M. The role of economic variables and $\mathrm{CO} 2$ emissions in examining the efficiency of national transportation systems. Int. J. Sustain. Transp. 2012, 6, 48-66. [CrossRef]

57. Holden, R.; Xu, B.; Greening, P.; Piecyk, M.; Dadhich, P. Towards a common measure of greenhouse gas related logistics activity using data envelopment analysis. Transp. Res. Part A Policy Pract. 2016, 91, 105-119. [CrossRef]

58. Melo, I.C.; Alves Junior, P.N.; Perico, A.E.; Guzman, M.G.S.; Rebelatto, D.A. do N. Benchmarking freight transportation corridors and routes with data envelopment analysis (DEA). Benchmarking An Int. J. 2018, 25, 713-742. [CrossRef]

59. Vasco Correa, C.A. Economic evaluation of current conditions of competition and efficiency of automotive and rail systems in Colombia. Energy Policy 2012, 46, 78-87. [CrossRef]

60. Kengpol, A.; Tuammee, S.; Tuominen, M. The development of a framework for route selection in multimodal transportation. Int. J. Logist. Manag. 2014, 25, 581-610. [CrossRef]

61. De Oliveira, A.E.; Cicolin, L.D. Evaluating the logistics performance of Brazils corn exports: A proposal of indicators. African J. Agric. Res. 2016, 11, 693-700.

62. Charnes, A.; Cooper, W.W.; Rhodes, E. Measuring the efficiency of decision making units. Eur. J. Oper. Res. 1978, 2, 429-444. [CrossRef]

63. Zhu, J. Quantitative Models for Performance Evaluation and Benchmarking, 2nd ed.; Hillier, F.S., Ed.; Springer: New York, NY, USA, 2009; Volume 1, ISBN 9780387859811.

64. He, D.; Gao, P.; Sun, Z.; Lau, Y.-Y. Measuring water transport efficiency in the Yangtze River Economic Zone, China. Sustainability 2017, 9, 2278. [CrossRef]

65. Fazlollahi, A.; Franke, U. Measuring the impact of enterprise integration on firm performance using data envelopment analysis. Int. J. Prod. Econ. 2018, 200, 119-129. [CrossRef]

66. Charnes, A.; Cooper, W.W.; Golany, B.; Seiford, L. Foundations of Data Envelopment Analysis for Pareto-Koopmans Efficient Empirical Production Function. J. Econom. 1985, 30, 91-107. [CrossRef]

67. Mahmoudi, R.; Emrouznejad, A.; Shetab-Boushehri, S.N.; Hejazi, S.R. The origins, development and future directions of data envelopment analysis approach in transportation systems. Socioecon. Plann. Sci. 2018, 1-15. [CrossRef]

68. Banker, R.D.; Charnes, A.; Cooper, W.W. Some Models for Estimating Technical and Scale Inefficiencies in Data Envelopment Analysis. Manage. Sci. 1984, 30, 1078-1092. [CrossRef]

69. Cooper, W.W.; Seiford, L.M.; Tone, K. Data Envelopment Analysis: A Comprehensive Text with Models, 2nd ed.; Cooper, W.W., Tone, L.M., Kaoro, S., Eds.; Springer Science+Business Media: Houston, TX, USA, 2007; ISBN 9780387452814.

70. Mohseni, P.; Borghei, A.M.; Khanali, M. Coupled life cycle assessment and data envelopment analysis for mitigation of environmental impacts and enhancement of energy efficiency in grape production. J. Clean. Prod. 2018, 197, 937-947. [CrossRef]

71. Gökşen, Y.; Doğan, O.; Özkarabacak, B. A Data Envelopment Analysis Application for Measuring Efficiency of University Departments. Procedia Econ. Financ. 2015, 19, 226-237. [CrossRef]

72. Nellthorp, J.; Mackie, P.; Bristow, A. Measurement and valuation of the impacts of transport initiatives; Institute for Transport Studies, University of Leeds: Leeds, UK, 1998; Volume 1.

73. Leal Junior, I.C. Modal Choice Method for Transporting Hazardous Products based on ECO-Efficiency Measures; Federal University of Rio de Janeiro - UFRJ: Rio de Janeiro, Brazil, 2010.

74. Baležentis, T.; Li, T.; Streimikiene, D.; Baležentis, A. Is the Lithuanian economy approaching the goals of sustainable energy and climate change mitigation? Evidence from DEA-based environmental performance index. J. Clean. Prod. 2016, 116, 23-31. [CrossRef]

75. Fleury, P. Logística no Brasil: situação atual e transição para uma economia verde; Martins, L., Corrêa, C., Eds.; Brazilian Foundation for Sustainable Development - FBDS: Rio de Janeiro, Brazil, 2012.

76. Zikopoulos, C. Determination of freight rates under stochastic demand and freight consolidation savings. Int. J. Prod. Res. 2018, 1-18. [CrossRef]

77. Dionísio, E.A.; de Freitas, W.J.; de Arruda Ignácio, P.S. Prospecção de cenários para uma cadeia agroexportadora de soja. Rev. Espac. 2015, 36, 1-12. 
78. BACEN Cotações e Boletins. Available online: https://www4.bcb.gov.br/pec/taxas/port/ptaxnpesq.asp (accessed on 24 April 2019).

79. Yang, H.; Pollitt, M. The necessity of distinguishing weak and strong disposability among undesirable outputs in DEA: Environmental performance of Chinese coal-fired power plants. Energy Policy 2010, 38, 4440-4444. [CrossRef]

80. Sahoo, B.K.; Luptacik, M.; Mahlberg, B. Alternative measures of environmental technology structure in DEA: An application. Eur. J. Oper. Res. 2011, 215, 750-762. [CrossRef]

81. Santos, A.B.; Sproesser, R.L. Caracterização e Avaliação da Eficiência dos Terminais Intermodais Brasileiros. Gestão Reg. 2013, 29, 47-63.

82. Brazil. Plano Nacional de Logística e Transportes (PNLT); Ministério dos Transportes (MT): Brasília, DF, Brazil, 2011.

83. Rech, L.R.; Morais, M.; Casarotto, E.L.; Binotto, E. Análise situacional das rodovias federais para o escoamento da produção do agronegócio em Mato Grosso do Sul e Mato Grosso. Rev. Do CCEI 2017, 22, 37-51.

84. De Souza, R.G.; Lins, M.P.E.; dos Bastos Valle, R.A. Comparison of urban solid waste collection systems in Brazil using data envelopment analysis. In Proceedings of the XLIII Simpósio Brasileiro de Pesquisa Operacional; SOBRAPO: Gramado, RS, Brazil, 2011; pp. 294-306.

(C) 2019 by the authors. Licensee MDPI, Basel, Switzerland. This article is an open access article distributed under the terms and conditions of the Creative Commons Attribution (CC BY) license (http://creativecommons.org/licenses/by/4.0/). 